-ORIGINAL ARTICLE-

Volume 13 Issue 42021

DOI: 10.21315/eimj2021.13.4.5

ARTICLE INFO

Received: 06-01-2021

Accepted: 05-08-2021

Online: 30-12-2021

\section{Audit on Clinical Competency of Fresh Medical Graduates in a Malaysian Private University Using Kirkpatrick Level-1 Evaluation Model}

\author{
Abdus Salam', Belqees Ahmed Qaid Allaw², Hamida Begum³, \\ Abdelbaset Taher Abdelhalim ${ }^{4}$, Alsayed Alsharkawy ${ }^{5}$, Khaled Mat \\ Hassan $^{3}$, Sapari Satwi ${ }^{6}$, Jamaludin Zainol ${ }^{7}$ \\ ${ }^{1}$ Medical Education Unit and Community Medicine Unit, Faculty of \\ Medicine, Widad University College, Pahang, MALAYSIA \\ ${ }^{2}$ Anatomy Unit, Faculty of Medicine, Widad University College, \\ Pahang, MALAYSIA \\ ${ }^{3}$ Obstetrics \& Gynaecology Unit, Faculty of Medicine, Widad \\ University College, Pahang, MALAYSIA \\ ${ }^{4}$ Pharmacology Unit, Faculty of Medicine, Widad University College, \\ Pahang, MALAYSIA \\ ${ }^{5}$ Paediatrics Unit, Faculty of Medicine, Widad University College, \\ Pahang, MALAYSIA \\ ${ }^{6}$ Internal Medicine Unit, Faculty of Medicine, Widad University \\ College, Pahang, MALAYSIA \\ ${ }^{7}$ Surgery Unit, Faculty of Medicine, Widad University College, \\ Pahang, MALAYSIA
}

To cite this article: Salam A, Allaw BAQ, Begum H, Abdelhalim AT, Alsharkawy A, Hassan KM, Satwi S, Zainol J. Audit on clinical competency of fresh medical graduates in a Malaysian private university using Kirkpatrick level-1 evaluation model. Education in Medicine Journal. 2021;13(4): 57-70. https://doi.org/10.21315/eimj2021.13.4.5

To link to this article: https://doi.org/10.21315/eimj2021.13.4.5

\begin{abstract}
Clinical competency is the core of the medical curriculum. Careful ongoing evaluation of clinical competency is required to ensure continuous reviewing for curriculum development. The objective of this study was to investigate self-perceptions of clinical competency of fresh medical graduates using the Kirkpatrick framework - the most convenient and widely used model for measuring clinical competency. A cross-sectional study was conducted among 50 fresh medical graduates of Widad University College, Malaysia in 2019 using a standardised questionnaire containing 43-items of competency. Respondents were asked to rate self-perceptions of his/her competency in these attributes using a five-point Likert scale against each attribute, where $5=$ always competent and $1=$ never competent. The response rate was $92 \%$. Out of 43 items, graduates were always competent in taking clinical history and examining a patient thoroughly; frequently competent in eight attributes; sometimes competent in 29; and occasionally competent in four. The graduates have not yet started their houseman-training; and thus, got fewer chances to practice all the procedures. It is expected that graduates' competency will improve during their houseman training. There is scope for improvement, as faculty need to pay more attention to improving student competency by arranging additional training. The teaching of clinical competency also needs integration with the pre-clinical phase for early exposure. The findings have direct implications for faculty development towards competency-based
\end{abstract}


education that would bridge the gap between education and practice. This study offers other medical schools a window towards comprehensive use of competency tools to assess the competency of their graduates.

Keywords: Audit, Clinical competency, Competency tool, Fresh medical graduates, Kirkpatrick model

Abdus Salam, Medical Education Unit and Community Medicine Unit, Faculty of Medicine, Widad University College, Bandar Indera Mahkota, 25200 Kuantan, Pahang, Malaysia

Email: abdussalam.dr@gmail.com

\section{INTRODUCTION}

Medicine is considered the "global profession of physicians" and requires universal essential competency that must be possessed by all physicians. This competency guides the teachers, students and physicians about what they are supposed to teach, what they are expected to learn and what universal educational experiences they should possess accordingly (1). Thus, globally medical schools provide educational experiences necessary for the acquisition of essential competency levels of their graduates regardless of where they receive their medical education from (2). Professional competency has been defined as the habitual and judicious use of communication, knowledge, technical skills, clinical reasoning, emotions, values and reflection in daily practice for the benefit of the individual and community being served (3). International institutions such as the General Medical Council (GMC), Accreditation Council for Graduate Medical Education (ACGME), the American Board of Internal Medicine (ABIM) and the Institute for International Medical Education (IIME), have set the list of competencies for medical graduates (47).

Clinical competency is one of the key domains of the professional competency of physicians (8) and is vital in terms of correct decision-making and successful care of the patient (9). Inadequate competency in the clinical skill can endanger patient safety (10) and may contribute to a stressful workplace for fresh graduates (11). It is reported that newly qualified doctors lack adequate skills necessary for internship duties (12). Their knowledge and skills have been reported to vary from individual to individual and also may not fulfil the faculty's expectations (13). Many studies have reported that a significant number of fresh medical graduates perceived their competency in basic procedures as inadequate $(2,14-$ 15). It has also been shown that explicit requirements in practical skills set by an institution are often not synchronised with the delivery of teaching $(2,16)$.

Clinical competency is considered as the core curriculum of medical education. Educational programmes are essentially related to the modification of students' knowledge, attitudes and abilities $(17-18)$. It is the objective of every medical school's curriculum globally to attain a satisfactory standard of clinical competency (19). Implementation of welldesigned clinical competency training in the core curriculum of the undergraduate medical education programme is vital to obtain the desired learning outcome of the programme. To maintain the quality, careful ongoing evaluation of these competency training is required. Since student learning is the goal of education, assessment of student learning would reflect the effectiveness of the programme and accomplishment of its core task (20). Therefore, along with proper planning and implementation, it is also important to perform curriculum evaluation accurately to check the capability of educational programmes, and to get data to allow 
faculty to determine if there is a need for any modification in the curriculum or programme (17).

There are different approaches and models available for the evaluation of a curriculum or educational programme. Kirkpatrick's four-level framework model is a commonly used model which measures: reactions at level-1, learning at level-2, behaviour at level-3 and results at level-4. Kirkpatrick's reaction level model investigates how the participants perceive the learning experience (21), and Kirkpatrick's learning level model identifies the knowledge and skills acquired after the training programme (17). Fresh medical graduates are expected to attain a certain level of required clinical competency after their completion of a five-year undergraduate medical course. Kirkpatrick's programme evaluation model is an excellent way to evaluate a curriculum by assessing the selfconfidence of the fresh graduates regarding their learning of clinical competency. Kirkpatrick's reaction level model is the most convenient and extensively employed model worldwide to evaluate the effectiveness of a curriculum by assessing self-assessment of graduates $(17,22)$, at the final stage of an educational programme (23).

The self-assessment of competency is considered the basis of adult education, particularly among medical practitioners. The confidence level is an important marker of competency that reflects the ability to function competently (24). Assessment of the self-confidence level in performing the clinical procedures is one of the ways to determine the learning gained. Selfconfidence reflects the ability to perform procedures competently without any supervision. Self-reported confidence level is the impact of knowledge gained through the educational process during training as well as their prior and current attitudes that ultimately lead to the final attitudinal changes. Although the influences of the practitioners' willingness to undertake procedures, accurate self-assessment and willingness to ask for support influences the confidence level. Thus, confidence level is an important target to maintain adequate competency and performance level (25). Bandura states that students who have high rated perception, are expected to work hard and ultimately attain better scores in tests (26).

In this study, we have evaluated the selfperceptions of clinical competency of fresh medical graduates immediately after their graduation prior to entering the houseman training. We analysed their competency based on gender and marital status as well, as these factors have been found to play a role in the perceived competency of medical students (27-28). The objective of this study was to investigate the perceptions of clinical competency of fresh medical graduates using Kirkpatrick's framework model to identify the efficiency of the curriculum aimed at continuous reviewing and its development.

\section{MATERIALS AND METHODS}

\section{Setting}

The setting of this research was a private teaching medical institution in Malaysia. This cross-sectional questionnaire survey, an audit on educational development was conducted among all 50 fresh medical graduates of Widad University College (WUC) who graduated in September 2019. This survey used Kirkpatrick's reaction level model of evaluation.

\section{Context}

The WUC, established as early as December 1997 as Institute Fitra with students of accounting matriculation, was subsequently upgraded to University College Shahputra (UCSA) in March 2011 when the MBBS programme was initiated. Afterward, UCSA was re-branded as WUC in mid-2016. The MBBS programme at WUC is modelled on an integrated 
curriculum with a pre-clinical phase of two years and a clinical phase comprised of three years (29). Students undergo 5 -year training, with emphasis given on acquiring basic competencies, along with professional and behavioural development from years 1 to 5 through lectures, PBL, small group discussions, seminars, workshops and exposure through the community and hospital environment to real patients (29). To improve the clinical competency, students attend a clinical skill laboratory to practice clinical procedures on mannequins before performing them on actual patients. Bedside teaching, simulation and standardisation methods are also used to improve clinical competency. The curriculum is designed to ensure that the graduates are competent in performing a range of items of clinical competency, provide their services ethically with leadership qualities, and are able to work independently without any supervision.

\section{Instrument}

A standardised questionnaire containing 43 items of clinical procedures was used in this study to collect the data. The clinical competency evaluated ranged from history taking, patient examination, head injury monitoring, neonatal resuscitation, assist in operations, interpretation of chest X-ray and performing various types of medical, surgical, obstetrical and gynecological clinical procedures. The 43 clinical attributes chosen for competency assessment were based on the content of the WUC medical curriculum, as well as a review of the literature (27). The content validity of the instrument was ensured through discussions with specialists in different fields of medical education while the face validity was ensured by administering the instrument to a similar group of students of an earlier session. The fresh medical graduates were asked to rate their selfperceived confidence about the mentioned competency items using a five-point Likert scale. The scale indicates $5=$ always competent, $4=$ frequently competent, 3
= sometimes competent, $2=$ occasionally competent and $1=$ never competent. The list of 43 items of competencies in the questionnaire was arranged in alphabetical order.

\section{Data Collection}

The questionnaire was administered to the participants at the end of an official meeting immediately after graduation. Before administering the questionnaire, anonymity was ensured, the purpose of the study was clearly explained, and consent to participate was obtained. Participants were informed that the participation was voluntary and assured that participation in this study will not hamper them in any way.

\section{Data Analysis}

All the data collected were compiled and analysed using SPSS version 22. The competency levels of the respondents are presented as median scores and interquartile range (IQR) against each of the competency. Comparisons between the two groups in terms of gender and marital status were performed using non-parametric MannWhitney $U$ test, as the data were not normally distributed. The significant level was $p<0.05$.

\section{RESULTS}

Out of 50 graduates, a total of 46 returned the questionnaire, for a response rate of $92 \%$. Table 1 reveals the distribution of gender and marital status of the respondents: $70 \%$ were female and $30 \%$ were male, while $74 \%$ were unmarried and $26 \%$ were married.

Table 2 shows the median competency scores of the graduates presented in descending order. Among 43 items of clinical competency, the highest score of 5 was obtained in taking clinical history thoughtfully; and examining a patient thoroughly. There were eight items where respondents rated competency 
score of 4, including selecting relevant investigations, interpreting chest X-ray, intravenous (IV) cannula insertion, venipuncture, administrating IV infusion/ drugs, wound dressing, administering per rectal medication and performing electrocardiogram (ECG). The median competency levels of the graduates in normal delivery were scored as 3.5 while another 28 competency items were scored at 3. The lowest scores were obtained in lumbar puncture, proctoscopy, amniotomy and hysteroscopy. None of the items was rated at score 1 by the participants.

Table 3 reveals the comparison of competency scores between two groups based on gender and marital status. There were no significant differences in competency between males and females except in skills number 37 where males were significantly more competent than females in mixing and injecting drugs into IV bags. Comparison between married and unmarried groups also did not show any significant differences, except in skill number 14, where married respondents were significantly more competent than the unmarried ones in giving a subcutaneous injection.

Table 1: Gender and marital status of fresh medical graduates, $n=46$

\begin{tabular}{lll}
\hline Variables & $\boldsymbol{n}$ & $\%$ \\
\hline Gender & & \\
Male & 14 & 30 \\
Female & 32 & 70 \\
Marital status & & \\
$\quad$ Married & 12 & 26 \\
Unmarried & 34 & 74 \\
\hline
\end{tabular}

Table 2: Competency of fresh graduates showed in median and IQR, $n=46$

\begin{tabular}{|c|c|c|c|c|c|}
\hline \multirow[t]{2}{*}{ No. } & \multirow{2}{*}{$\begin{array}{l}\text { Competencies/ } \\
\text { practical skills }\end{array}$} & $\begin{array}{c}\text { Always } \\
\text { competent }\end{array}$ & $\begin{array}{l}\text { Frequently } \\
\text { competent }\end{array}$ & $\begin{array}{l}\text { Sometimes } \\
\text { competent }\end{array}$ & $\begin{array}{l}\text { Occasionally } \\
\text { competent }\end{array}$ \\
\hline & & Median (IQR) & Median (IQR) & Median (IQR) & Median (IQR) \\
\hline 1 & $\begin{array}{l}\text { Taking clinical history } \\
\text { thoughtfully }\end{array}$ & $5(1)$ & - & - & - \\
\hline 2 & $\begin{array}{l}\text { Examine a patient } \\
\text { thoroughly }\end{array}$ & $5(1)$ & - & - & - \\
\hline 3 & $\begin{array}{l}\text { Selecting relevant } \\
\text { investigations }\end{array}$ & - & $4(2)$ & - & - \\
\hline 4 & Interpreting chest X-ray & - & $4(2)$ & - & - \\
\hline 5 & IV cannula insertion & - & $4(2)$ & - & - \\
\hline 6 & Venipuncture & - & $4(2)$ & - & - \\
\hline 7 & $\begin{array}{l}\text { Administrating IV } \\
\text { infusion/drugs }\end{array}$ & - & $4(1)$ & - & - \\
\hline 8 & Wound dressing & - & $4(1)$ & - & - \\
\hline 9 & $\begin{array}{l}\text { Administering per rectal } \\
\text { medications }\end{array}$ & - & $4(1)$ & - & - \\
\hline 10 & Performing ECG & - & $4(1)$ & - & - \\
\hline 11 & Normal delivery & - & - & $3.5(1)$ & - \\
\hline 12 & Scrubbing for surgery & - & - & $3(2)$ & - \\
\hline
\end{tabular}


Table 2 (continued)

\begin{tabular}{|c|c|c|c|c|c|}
\hline \multirow[t]{2}{*}{ No. } & \multirow{2}{*}{$\begin{array}{l}\text { Competencies/ } \\
\text { practical skills }\end{array}$} & $\begin{array}{l}\text { Always } \\
\text { competent }\end{array}$ & $\begin{array}{l}\text { Frequently } \\
\text { competent }\end{array}$ & $\begin{array}{l}\text { Sometimes } \\
\text { competent }\end{array}$ & $\begin{array}{l}\text { Occasionally } \\
\text { competent }\end{array}$ \\
\hline & & Median (IQR) & Median (IQR) & Median (IQR) & Median (IQR) \\
\hline 13 & $\begin{array}{l}\text { Insertion of urinary } \\
\text { catheter }\end{array}$ & - & - & $3(1)$ & - \\
\hline 14 & $\begin{array}{l}\text { Giving a subcutaneous } \\
\text { injection }\end{array}$ & - & - & $3(1)$ & - \\
\hline 15 & Removal of sutures & - & - & $3(1)$ & - \\
\hline 16 & $\begin{array}{l}\text { Suturing superficial } \\
\text { wound }\end{array}$ & - & - & $3(3)$ & - \\
\hline 17 & Giving an IV injection & - & - & $3(1)$ & - \\
\hline 18 & $\begin{array}{l}\text { Using an } \\
\text { ophthalmoscope }\end{array}$ & - & - & $3(1)$ & - \\
\hline 19 & $\begin{array}{l}\text { Giving an intramuscular } \\
\text { (IM) injection }\end{array}$ & - & - & $3(1)$ & - \\
\hline 20 & Mask ventilation & - & - & $3(3)$ & - \\
\hline 21 & $\begin{array}{l}\text { Removing plaster of } \\
\text { Paris (POP) }\end{array}$ & - & - & $3(2)$ & - \\
\hline 22 & Applying POP & - & - & $3(1)$ & - \\
\hline 23 & $\begin{array}{l}\text { Inserting nasogastric } \\
\text { tube }\end{array}$ & - & - & $3(2)$ & - \\
\hline 24 & Rectal examination & - & - & $3(2)$ & - \\
\hline 25 & $\begin{array}{l}\text { Basic life support - } \\
\text { Cardiopulmonary } \\
\text { resuscitation (CPR) }\end{array}$ & - & - & $3(2)$ & - \\
\hline 26 & Arterial blood taking & - & - & $3(2)$ & - \\
\hline 27 & $\begin{array}{l}\text { Preparing equipment } \\
\text { for intubation }\end{array}$ & - & - & $3(2)$ & - \\
\hline 28 & $\begin{array}{l}\text { Manual removal of } \\
\text { placenta }\end{array}$ & - & - & $3(2)$ & - \\
\hline 29 & Using an auroscope & - & - & $3(1)$ & - \\
\hline 30 & Assisting in operations & - & - & $3(1)$ & - \\
\hline 31 & Incision and drainage & - & - & $3(1)$ & - \\
\hline 32 & $\begin{array}{l}\text { Using a pump to give } \\
\text { drug treatment }\end{array}$ & - & - & $3(1)$ & - \\
\hline 33 & Endotracheal intubation & - & - & $3(1)$ & - \\
\hline 34 & Head injury monitoring & - & - & $3(1)$ & - \\
\hline 35 & Cricoid's pressure & - & - & $3(1)$ & - \\
\hline 36 & Neonatal resuscitation & - & - & $3(1)$ & - \\
\hline
\end{tabular}


Table 2 (continued)

\begin{tabular}{lllccc}
\hline No. & $\begin{array}{l}\text { Competencies/ } \\
\text { practical skills }\end{array}$ & $\begin{array}{c}\text { Always } \\
\text { competent }\end{array}$ & $\begin{array}{c}\text { Frequently } \\
\text { competent }\end{array}$ & $\begin{array}{c}\text { Sometimes } \\
\text { competent }\end{array}$ & $\begin{array}{c}\text { Occasionally } \\
\text { competent }\end{array}$ \\
\cline { 2 - 6 } & Median (IQR) & Median (IQR) & Median (IQR) & Median (IQR) \\
\hline 37 & $\begin{array}{l}\text { Mixing and injecting } \\
\text { drugs into an IV bag }\end{array}$ & - & - & $3(3)$ & - \\
38 & $\begin{array}{l}\text { Exchange transfusion } \\
39\end{array}$ & - & - & $3(3)$ & - \\
40 & Ventous delivery & - & - & $3(1)$ & - \\
41 & $\begin{array}{l}\text { Pumbar puncture } \\
42\end{array}$ & - & - & - & $2(2)$ \\
43 & Amniotomy & - & - & - & $2(1)$ \\
\hline
\end{tabular}

Table 3: Comparison based on gender and marital status of fresh graduates, $n=46$

\begin{tabular}{|c|c|c|c|c|c|c|c|}
\hline \multirow{3}{*}{ No. } & \multirow{3}{*}{$\begin{array}{l}\text { Competencies/ } \\
\text { practical skills }\end{array}$} & \multicolumn{2}{|c|}{ Gender } & \multirow{3}{*}{$p$} & \multicolumn{2}{|c|}{ Marital status } & \multirow{3}{*}{$p$} \\
\hline & & Female & Male & & Married & Unmarried & \\
\hline & & Median (IQR) & Median (IQR) & & Median (IQR) & Median (IQR) & \\
\hline 1 & $\begin{array}{l}\text { Taking clinical history } \\
\text { thoughtfully }\end{array}$ & $5(2)$ & $5(0)$ & 0.29 & $5(2)$ & $5(2)$ & 0.61 \\
\hline 2 & $\begin{array}{l}\text { Examine a patient } \\
\text { thoroughly }\end{array}$ & $5(1)$ & $5(0.7)$ & 0.28 & $5(1)$ & $5(1)$ & 0.63 \\
\hline 3 & $\begin{array}{l}\text { Selecting relevant } \\
\text { investigations }\end{array}$ & $4(2)$ & $4(2)$ & 0.78 & $4(2)$ & $4(2)$ & 0.79 \\
\hline 4 & Interpreting chest X-ray & $4(2)$ & $5(2)$ & 0.35 & $4(1.8)$ & $4(2)$ & 0.87 \\
\hline 5 & IV cannula insertion & $4(2)$ & $4(2)$ & 0.64 & $3.5(2)$ & $4(2)$ & 0.98 \\
\hline 6 & Venipuncture & $4(2)$ & $3.5(1)$ & 0.45 & $3(1)$ & $4(2)$ & 0.07 \\
\hline 7 & $\begin{array}{l}\text { Administrating IV } \\
\text { infusion/drugs }\end{array}$ & $3.5(1)$ & $4(1)$ & 0.42 & $4(2)$ & $4(1)$ & 0.44 \\
\hline 8 & Wound dressing & $3(2)$ & $4(1)$ & 0.61 & $3(2)$ & $4(1)$ & 0.38 \\
\hline 9 & $\begin{array}{l}\text { Administering per rectal } \\
\text { medications }\end{array}$ & $3(2)$ & $2.5(1)$ & 0.48 & $3(2)$ & $3(2)$ & 0.94 \\
\hline 10 & Performing ECG & $3(3)$ & $4(1)$ & 0.33 & $4(2)$ & $3(1)$ & 0.33 \\
\hline 11 & Normal delivery & $3(2)$ & $3.5(1)$ & 0.96 & $3(2)$ & $3.5(1)$ & 0.35 \\
\hline 12 & Scrubbing for surgery & $3(3)$ & $4(2)$ & 0.26 & $3(2)$ & $4(2)$ & 0.86 \\
\hline 13 & $\begin{array}{l}\text { Insertion of urinary } \\
\text { catheter }\end{array}$ & $3(2)$ & $3.5(1)$ & 0.85 & $3(2)$ & $3(1)$ & 0.52 \\
\hline 14 & $\begin{array}{l}\text { Giving a sub-cutaneous } \\
\text { injection }\end{array}$ & $3(1)$ & $3.7(1)$ & 0.39 & $4(1.8)$ & $3(1)$ & $0.04^{*}$ \\
\hline 15 & Removal of sutures & $3(2)$ & $4(1)$ & 0.51 & $4(3)$ & $3(1)$ & 0.50 \\
\hline
\end{tabular}


Table 3 (continued)

\begin{tabular}{|c|c|c|c|c|c|c|c|}
\hline \multirow{3}{*}{ No. } & \multirow{3}{*}{$\begin{array}{l}\text { Competencies/ } \\
\text { practical skills }\end{array}$} & \multicolumn{2}{|c|}{ Gender } & \multirow{3}{*}{$p$} & \multicolumn{2}{|c|}{ Marital status } & \multirow{3}{*}{$p$} \\
\hline & & Female & Male & & Married & Unmarried & \\
\hline & & Median (IQR) & Median (IQR) & & Median (IQR) & Median (IQR) & \\
\hline 16 & $\begin{array}{l}\text { Suturing superficial } \\
\text { wound }\end{array}$ & $3(3)$ & $3(2)$ & 0.53 & $3(3)$ & $3(3)$ & 0.85 \\
\hline 17 & Giving an IV injection & $3(2.8)$ & $3.7(1)$ & 0.44 & $3.5(1.8)$ & $3(2)$ & 0.30 \\
\hline 18 & $\begin{array}{l}\text { Using } \\
\text { an ophthalmoscope }\end{array}$ & $3(3)$ & $3(0)$ & 0.98 & $3(2)$ & $3(1)$ & 0.52 \\
\hline 19 & Giving an IM injection & $3(1.8)$ & $3(1)$ & 0.70 & $3.5(1)$ & $3(1.3)$ & 0.29 \\
\hline 20 & Mask ventilation & $3(2)$ & $3.5(2)$ & 0.14 & $3(2)$ & $3(3)$ & 0.62 \\
\hline 21 & Removing POP & $3(2)$ & $3(1)$ & 0.60 & $3(1)$ & $3(1)$ & 0.16 \\
\hline 22 & Applying POP & $3(2)$ & $3(1)$ & 0.42 & $3(1)$ & $3(1)$ & 0.19 \\
\hline 23 & $\begin{array}{l}\text { Inserting naso-gastric } \\
\text { tube }\end{array}$ & $3(2)$ & $3(2)$ & 0.77 & $3(2)$ & $3(2)$ & 0.82 \\
\hline 24 & Rectal examination & $3(2)$ & $3(0)$ & 0.75 & $3(2)$ & $3(2)$ & 0.38 \\
\hline 25 & Basic life support - CPR & $3(2)$ & $3(1)$ & 0.36 & $3(3)$ & $3(1)$ & 0.55 \\
\hline 26 & Arterial blood taking & $3(2)$ & $3(1)$ & 0.40 & $3(3)$ & $3(2)$ & 0.91 \\
\hline 27 & $\begin{array}{l}\text { Preparing equipment for } \\
\text { intubation }\end{array}$ & $2.5(2)$ & $3(1)$ & 0.08 & $3(2)$ & $3(2)$ & 0.21 \\
\hline 28 & $\begin{array}{l}\text { Manual removal of } \\
\text { placenta }\end{array}$ & $3(2)$ & $3(1)$ & 0.97 & $2.5(3)$ & $3(2)$ & 0.99 \\
\hline 29 & Using an auroscope & $3(1)$ & $3(1)$ & 0.79 & $3(3)$ & $3(1)$ & 0.28 \\
\hline 30 & Assisting in operations & $3(2)$ & $3(1)$ & 0.90 & $3(3)$ & $3(1)$ & 0.95 \\
\hline 31 & Incision and drainage & $3(1)$ & $3(0)$ & 0.21 & $3(3)$ & $3(1)$ & 1.00 \\
\hline 32 & $\begin{array}{l}\text { Using pump to give } \\
\text { drug treatment }\end{array}$ & $3(2)$ & $3(0)$ & 0.17 & $3(1)$ & $3(1)$ & 0.73 \\
\hline 33 & Endotracheal intubation & $3(1)$ & $2.5(1)$ & 0.44 & $2(2)$ & $3(1)$ & 0.24 \\
\hline 34 & Head injury monitoring & $3(1.8)$ & $3(0.5)$ & 0.33 & $3(1.8)$ & $3(1)$ & 0.87 \\
\hline 35 & Cricoid's pressure & $3(2)$ & $2.5(2)$ & 0.56 & $2(3)$ & $3(1)$ & 0.73 \\
\hline 36 & Neonatal resuscitation & $3(2)$ & $2(1)$ & 0.83 & $2.5(3)$ & $3(1)$ & 0.95 \\
\hline 37 & $\begin{array}{l}\text { Mixing and injecting } \\
\text { drugs into IV bag }\end{array}$ & $2(2)$ & $3.5(1)$ & $0.01 *$ & $3(3)$ & $3(3)$ & 0,73 \\
\hline 38 & Exchange transfusion & $2.8(2)$ & $3(2.3)$ & 0.45 & $3(2.8)$ & $3(2.3)$ & 0.88 \\
\hline 39 & Ventous delivery & $3(1)$ & $2.5(1)$ & 0.43 & $3(2)$ & $3(1)$ & 0.78 \\
\hline 40 & Lumbar puncture & $2(2)$ & $2(1)$ & 0.95 & $2.5(3)$ & $2(2)$ & 0.36 \\
\hline 41 & Proctoscopy & $2(2)$ & $2.5(1)$ & 0.12 & $3(1)$ & $2(2)$ & 0.17 \\
\hline 42 & Amniotomy & $2.5(2)$ & $2(2)$ & 0.24 & $1.5(2)$ & $2(2)$ & 0.34 \\
\hline 43 & Hysteroscopy & $2.5(2)$ & $2(1)$ & 0.45 & $1.5(2)$ & $2(1)$ & 0.18 \\
\hline
\end{tabular}

Note: ${ }^{*}$-value is significant $(<0.05)$. 


\section{DISCUSSION}

This present study has revealed the selfassessment reports of fresh medical graduates in terms of the necessary clinical competency in various attributes that they should achieve during their undergraduate courses. This reflects their preparedness for their future professional practice. Median competency scores in different procedures ranged from 2 to 5 . The 10 clinical competencies which scored as 4 to 5 are essential in their daily activities as a competent houseman. The highest level of competency was exhibited in the art of taking clinical history thoughtfully and examining a patient thoroughly, meaning they were always competent in these two attributes. This finding is consistent with the findings in other studies as well (14, $27,30)$. It is very important to become a master in taking an accurate clinical history and performing a thorough clinical examination. About $79 \%$ of patients can be diagnosed if one can take the history accurately and thoughtfully, and a further $8 \%$ can be diagnosed if one examines the patient thoroughly (31). Therefore, proper history-taking and physical examination are very important practices which are confidently and competently performed by our graduates.

The next common frequently exhibited clinical competencies included selecting relevant investigation, interpretation of chest X-rays, IV cannula insertion, venipuncture, administering IV infusion / drugs, wound dressing, administering per rectal medication and performing ECG. A previous study has shown similarity in the competency of IV cannula insertion, venipuncture and ECG (14). Competency in X-ray interpretation was found to be improved with training (32). Capability of interpretation of chest X-ray is a vital skill for the house officers in an emergency to manage the patients before being seen by the specialist for various conditions such as pneumothorax, pneumo-mediastinum, pneumo-peritoneum, etc. (32). An ECG is also an essential tool for the diagnosis of coronary heart disease (33) and house officers need to have a basic knowledge of it.

The graduates rated the competency of obstetrical procedure of normal delivery as 3.5 , while competency in handling complications of delivery such as manual removal of placenta and ventouse delivery was rated 3, indicating that they are sometimes competent in those skills. Competency level in newborn resuscitation was also rated as sometimes competent, which is consistent with a study in Thailand that showed that neonatal resuscitation was the lowest scored competency among fresh graduates. Neonatal resuscitation, being a complicated procedure, is usually managed by paediatric residents or staff doctors in an emergency, which creates less opportunity for inexperienced juniors (34). CPR is another attribute of clinical competency that was rated as sometimes competent in this study. The CPR is a basic life support technique, and can be lifesaving in many emergency situations. As such, we expect the competency score to be more in this category. It is expected that medical professionals at the end of their undergraduate programme can perform proper CPR (35). A study of South African graduates showed insufficient skills in CPR (11). A previous study in Malaysia also showed that there was a lack of confidence among junior doctors in the resuscitation of patients in real situations. Faculty needs to give more emphasis on CPR and provide frequent trainings to build up confidence of graduates in this procedure (36). Our graduates need much more exposure to real life situations to be more confident and competent in this regard.

There were four items of skills which were reported as occasionally competent. This could be due to the fact that these are considered as advanced procedures, and usually the experienced seniors perform these procedures, where new graduates receive the least exposure. Again, it may raise the argument on whether all these procedures are core competency for fresh 
medical graduates or more senior doctors. Indeed, a great level of competency is attained by a doctor after graduation from real life experiences by managing patients throughout their career $(2,14$, 37). Therefore, it is important to determine the core clinical competency that every medical student must be able to perform competently on graduation. This present study showed that graduates did not get enough training to perform competently and confidently some of the necessary skills required. Medical students need more training through exposure of real patient as well as by the use of simulated and standardised patients. Simulation is an important way to gain competency in a safe and non-threatening learning environment, and thereby increases the students' confidences in performing the procedures (38). Standardised patients in teaching clinical skills allow students to improve their competencies (27). Educational managers especially need to consider this suggestion. We also suggest integrating the teaching of the core clinical skills in the pre-clinical curriculum for early exposure to clinical knowledge.

Comparison based on gender and marital status did not show any significant difference except only for two items. Male respondents were significantly more competent than females in mixing and injecting drugs into IV bags $(p=0.01)$, while married respondents were significantly more competent than unmarried in giving a subcutaneous injection $(p=0.04)$. Previous reports showed that gender could affect the self-confidence in performing clinical procedures, although no reasons were found $(27,39)$. Marital status showed no association with self-confidence in performing clinical skills (27). However, it is evidenced that marital status has a significant effect on academic performance of the students (40), which might influence them to achieve higher level of competencies.
Other factors that can affect the attainment of the competency are learners' proficiency, learning capacity, interest to perform a procedure, as well as opportunities available to practice the procedure (41). In the clinical placement, lack of facility, lack of supervision and disproportionately increased number of students' posting may hamper the students in gaining the actual competency (42). Therefore, educational managers must consider all of these factors to improve the competency of medical graduates. Curriculum development cannot be attained without faculty development (29). In WUC, a strategic faculty development planner is proposed by the medical education unit and implemented regularly on key educational issues. A regular faculty development programme by a well-trained trainer is also fundamental to enhance the teaching-learning and assessment methodologies. This is to promote a competency-based education and thereby to ensure the production of confident and competent future medical professionals (29).

The graduates in this study have not yet started the houseman training and thus have had fewer chances to practice all procedures. Therefore, we expect that they will become more competent in the future with further training and dealing with real patients, and consequently become fit to serve the real working place. A previous study on medical students in their final six months of training showed that their competency in dealing with difficult patients did not meet expectations (14). Various reasons were suspected such as fear or anxiety of committing errors on live patients or disturbing the doctor-patient relationship balance which was maintained by more proficient doctors. During undergraduate training, students may not expect to attain true proficiency in all common practical procedure (14). It is accepted that the clinical competency is acquired from experience in managing real-life patients throughout a doctor's career $(2,14)$. 
High-quality teaching and training are central to high-quality patient care (2). Competency-based education bridges the gap between education and practice. In competency-based education, first of all, learning outcomes or competencies are identified (43) and then specific teaching and assessment methods are chosen to ensure effective learning (44). Teachinglearning is an interaction between teacher and learner to provide opportunities for learning (29). Teachers need to interact closely with students by playing a good role model and mentor for them, especially during the clinical years. Low facultystudent ratios are also needed to impart the desired knowledge, attitudes and performance changes in students (45). During faculty and curriculum development activities, identification of objectives/ outcomes, selection of contents, methods of content deliveries and methods of assessment procedures of outcomes must be set aligned with each other (46-47). Assessment drives learning, while learning drives practice. Meaningful assessment methods are crucial to the implementation of competency-based medical education (48). Students who were oriented on assessment methods in clinical practice and received constructive feedback from their teachers were nearly two times more confident clinically (49). A well-structured schedule of clerkship session in a real environment is very much essential for students' learning (4).

This study involves a very small sample, conducted from only one medical school, and based only on self-claims based data without any triangulation or verification of the self-claims which are the limitations of the study. Further triangulated studies involving various medical schools and approaches with large samples are required to get more information regarding these issues. However, the findings of this study are important for further professional development. This paper not only adds knowledge to a particular medical school but also offers other medical schools at national and international levels a window to comprehensive use of competency tools for assessment of clinical competency of their fresh medical graduates.

\section{CONCLUSION}

This present study showed that out of 43 attributes of clinical competency, graduates were always competent in the art of taking clinical history thoughtfully and examine a patient thoroughly; they were frequently competent in eight attributes, sometimes competent in 29 attributes, and occasionally competent in four attributes. The graduates have yet not started the houseman-training; it is hoped that graduates' competency levels will be further improved with time during their training from the real experiences with patients. There is scope for improvement, particularly in the attributes which were rated as sometimes competent and occasionally competent. Further curriculum development needs to be done addressing the identified areas of low competencies and educational managers should give due importance in this regard. Clinical competency instruction needs to be integrated with the pre-clinical phase for early exposure. Regular faculty development programme needs to be carried out to ensure a competency-based education by bridging the gap between education and practice.

\section{ACKNOWLEDGEMENTS}

The authors would like to thanks all the respondents for their participation in this study. This research did not receive any grant from any funding agencies and the authors have no conflict of interest to declare. 


\section{REFERENCES}

1. Schwarz MR, Wojtczak A. Global minimum essential requirements: a road towards competence-oriented medical education. Med Teach. 2002;24(2):125-9. https://doi. org/10.1080/01421590220120740

2. Salam A, Zainuddin $\mathrm{Z}$, Latiff $\mathrm{AA}, \mathrm{Ng}$ SP, Soelaiman IN, Mohamad $\mathrm{N}$, et al. Assessment of medical graduates competencies. Ann Acad Med Singap. 2008;37(9):814-6.

3. Epstein RM, Hundert EM. Defining and assessing professional competence. JAMA. 2002;287(2):226-35. https://doi. org/10.1001/jama.287.2.226

4. General Medical Council [Internet]. 2018 [cited 2020 April 2]. Outcomes for graduates; [p. 1-24]. Available from: https:// www.gmc-uk.org/-/media/documents/ dc11326-outcomes-for-graduates-2018_pdf75040796.pdf

5. Kavic MS. Competency and the six core competencies. JSLS. 2002;6(2):95-7.

6. American Board of Internal Medicine. Portfolio for internal medicine residency programs. Philadelphia: American Board of Internal Medicine; 2001.

7. Core Committee, Institute for International Medical Education (IIME). Global minimum essential requirements in medical education. Med Teach. 2002;24:130-5. https://doi.org/10.1080/01421590220120731

8. Offiah G, Ekpotu LP, Murphy S, Kane D, Gordon A, O'Sullivan M, et al. Evaluation of medical student retention of clinical skills following simulation training. BMC Med Educ. 2019;19:263. https://doi.org/10.1186/ s12909-019-1663-2

9. Omori DM, Wong RY, Antonelli MA, Hemmer PA. Introduction to clinical medicine: a time for consensus and integration. Am J Med. 2006;118:18994. https://doi.org/10.1016/j. amjmed.2004.11.017
10. Tekian A. Have newly graduated physicians mastered essential clinical skills? Med Educ. 2002;36:406-7. https://doi.org/10.1046/ j.1365-2923.2002.01214.x

11. Burch VC, Nash RC, Zabow T, Gibbs T, Aubin L, Jacobs B, et al. A structured assessment of newly qualified medical graduates. Med Educ. 2005;39:72331. https://doi.org/10.1111/j.13652929.2005.02192.x

12. Evans DE, Wood DF, Roberts CM. The effect of an extended hospital induction on perceived confidence and assessed clinical skills of newly qualified pre-registration house officers. Med Educ. 2004;38:9981001. https://doi.org/10.1111/j.13652929.2004.01908.x

13. Abadel FT, Hattab AS. How does the medical graduates' self-assessment of their clinical competency differ from experts' assessment? BMC Med Educ. 2013;13:24. https://doi.org/10.1186/1472-6920-13-24

14. Lai NM, Sivalingam N, Ramesh JC. Medical students in their final six months of training: progress in self-perceived clinical competence, and relationship between experience and confidence in practical skills. Singapore Med J. 2007;48:1018-27.

15. Taylor DM. Undergraduate procedural skills training in Victoria: is it adequate? Med J Aust. 1997;166:251-4. https://doi. org/10.5694/j.1326-5377.1997.tb140106.x

16. Sanders CW, Edwards JC, Burdenski TK. A survey of basic technical skills of medical students. Acad Med. 2004;79:873-5. https:// doi.org/10.1097/00001888-20040900000013

17. ULUM OG. Program evaluation through Kirkpatrick's framework. Pacific Business Review International. 2015;8(1):106-11.

18. Frye AV, Hemmer PA. Program evaluation models and related theories: AMEE guide no. 67. Med Teach. 2012;34(5):e28899. https://doi.org/10.3109/014215 9X.2012.668637 
19. Hassan S. How to develop a core curriculum in clinical skills for undergraduate medical teaching in the school of medical sciences at universiti sains malaysia? Malays J Med Sci. 2007;14(2):4-10.

20. Praslova L. Adaptation of Kirkpatrick's four level model of training criteria to assessment of learning outcomes and program evaluation in higher education. Educ Asse Eval Acc. 2010;22:215-25. https://doi. org/10.1007/s11092-010-9098-7

21. Kirkpatrick DL. Evaluating training programs: the four levels. 2nd ed. San Francisco: Berrett-Koehler; 1998.

22. Arthur W, Bennett, Edens PS and Bell ST. Effectiveness of training in organizations: a meta-analysis of design and evaluation features. J App Psychol. 2003;88(2):234-45. https://doi.org/10.1037/0021-9010.88.2.234

23. Nelson B, Dailey P. Four steps for evaluating recognition programs. Workforce. 1999;78(2):74-8.

24. Barnsley L, Lyon PM, Ralston SJ, Hibbert EJ, Cunningham I, Gordon FC, et al. Clinical skills in junior medical officers: a comparison of self-reported confidence and observed competence. Med Educ. 2004;38(4):358-67. https://doi.org/10.1046/ j.1365-2923.2004.01773.x

25. Byrne AJ, Blagrove MT, McDougall SJP. Dynamic confidence during simulated clinical tasks. Postgrad Med J. 2005;81:7858. https://doi.org/10.1136/pgmj.2004.029942

26. Bandura, A. Self-efficacy: the exercise of control. New York: W. H. Freeman; 1997.

27. Karim JA, Marwan YA, Dawas AM, Akhtar S. Self-confidence of medical students in performing clinical skills acquired during their surgical rotation. Saudi Med J. 2012;33(12):1310-6.
28. Blanch-Hartigan D, Hall JA, Roter D, Frankel R. Medical student gender and issues of confidence. Patient Education and Counseling. 2008;72(3):374-81. https://doi. org/10.1016/j.pec.2008.05.021

29. Salam A, Mohamad MB. Teachers' perception on what makes teaching excellence: impact of faculty development programme. Int Med J. 2020;27(1):1-4.

30. Miles S, Kellett J, Leinster SJ. Medical graduates' preparedness to practice: a comparison of undergraduate medical school training. BMC Med Educ. 2017;17:33. https://doi.org/10.1186/s12909-017-0859-6

31. Roshan R, Rao AP. A study of relative contributions of the history, physical examination and investigations in making medical diagnosis. J Assoc Physicians India. 2000;48(8):771-5.

32. Eisen LA, Berger JS, Hegde A, Schneider RF. Competency in chest radiography: a comparison of medical students, residents, and fellows. J Gen Intern Med. 2006;21:460-5. https://doi.org/10.1111/ j.1525-1497.2006.00427.x

33. Emmanuel $M$, Jean-Benoît $H$, Julien S, Eric B, Gilles P, Bernard P, et al. e-Learning versus lecture-based courses in ECG interpretation for undergraduate medical students: a randomized noninferiority study. Eur J Emerg Med. 2016;23(2):108-13. https://doi.org/10.1097/ MEJ.0000000000000215

34. Suwanrath C, Samphao S, Prechawai C, Singha P. Confidence in essential procedural skills of Thai medical graduates. IJOCS. 2016;10(1):6-10. https://doi.org/10.4172/ Clinical-Skills. 1000102

35. Baldi E, Savastano S, Contri E, Lockey A, Conaghan P, Hulme J, et al. Mandatory cardiopulmonary resuscitation competencies for undergraduate healthcare students in Europe. Eur J Anaesthesiol. 2020;37:839-41. https://doi.org/10.1097/ EJA.0000000000001272 
36. Chew KS, Mohd Hashairi F, Ida Zarina Z, Shaik Farid AW, Abu Yazid MN, Nik Hisamuddin NAR. A survey on the knowledge, attitude and confidence level of adult cardiopulmonary resuscitation among junior doctors in Hospital Universiti Sains Malaysia and Hospital Raja Perempuan Zainab II, Kota Bharu, Kelantan, Malaysia. Med J Malaysia. 2011;66(1):56-9.

37. Harrell PL, Keari GW, Reed EL, Grigsby DG, Caudill TS. Medical students' confidence and the characteristics of their clinical experiences in a primary care clerkship. Acad Med. 1993;68:5779. https://doi.org/10.1097/00001888199307000-00020

38. Peixoto AJ. Birth, death, and resurrection of the physical examination: clinical and academic perspectives on bedside diagnosis. Yale J Biol Med. 2001;74:221-8.

39. Connick RM, Connick P, Klotsas AE, Tsagkaraki PA, Gkrania-Klotsas E. Procedural confidence in hospital based practitioners: implications for the training and practice of doctors at all grades. BMC Med Educ. 2009;9:2. https://doi. org/10.1186/1472-6920-9-2

40. Petrol MB. Characteristics of married female NCE students in Kashim Ibrahim College of Education. Outreach Journal of Research Issues and Ideas. 2010;9:93-105.

41. $\mathrm{Yu}$ S-R, Cheng Y-C, Tseng H-M, Chang Y-C, Ma S-D, Huang C-D, et al. Undergraduates preparedness for practice is associated with professional identity and perception of educational environment: a validation study. Biomed J. 2020;1-9. https://doi.org/10.1016/j.bj.2020.04.009

42. Sánchez del Hierro G, Remmen R, Verhoeven V, Royen PV, Hendrickx K. Are recent graduates enough prepared to perform obstetric skills in their rural and compulsory year? A study from Ecuador. BMJ Open. 2014;4:e005759. https://doi. org/10.1136/bmjopen-2014-005759
43. Robert E, Terri C, Adrian JB, Jessica D, Janet B, Carol AA. Toward a common taxonomy of competency domains for the health professions and competencies for physicians. Acad Med. 2013;88(8):108894. https://doi.org/10.1097/

ACM.0b013e31829a3b2b

44. Taha WS. A guide to developing a competency-based curriculum for a residency training program - orthopaedic prospective. J Taibah Univ Med Sc. $\quad 2015 ; 10(1): 109-15$. https://oi. org/10.1016/j.jtumed.2015.02.004

45. Loftus S. Competencies in medical education: a trap for the unwary. Med Sci Educ. 2016;26:499-502. https://doi. org/10.1007/s40670-016-0269-0

46. Salam A. Input, process and output: system approach in education to assure the quality and excellence in performance. Bangladesh J Med Sci. 2015;14(1):1-2. https://doi. org/10.3329/bjms.v14i1.21553

47. Salam A. Issues of objective, content, method and assessment in the development of relevant curriculum in medical schools. Malaysian Med Assoc. 2010;4:22-4.

48. Tesfaye TS, Alemu W, Mekonen T. Perceived clinical practice competency and associated factors among undergraduate students of medicine and health science collage in Dilla University, SNNPR, Ethiopia. Adv Med Educ Pract. 2020;11:131-7. https://doi.org/10.2147/ AMEP.S235823

49. Rich JV, Young SF, Donnelly C, Hall AK, Dagnone JD, Weersink $\mathrm{K}$, et al. Competency-based education calls for programmatic assessment: but what does this look like in practice? J Eval Clin Pract. 2019;26:1087-95. https://doi.org/10.1111/ jep. 13328 